\title{
BMJ Open Integrated Primary Care Teams (IPCT) pilot project in Quebec: a protocol paper
}

\section{Damien Contandriopoulos, ${ }^{1}$ Arnaud Duhoux, ${ }^{1}$ Bernard Roy, ${ }^{2}$ Maxime Amar, ${ }^{3}$ Jean-Pierre Bonin, ${ }^{1}$ Roxane Borges Da Silva, ${ }^{1}$ Isabelle Brault, ${ }^{1}$ Clémence Dallaire ${ }^{2}$ Carl-Ardy Dubois, ${ }^{1}$ Francine Girard, ${ }^{1}$ Emmanuelle Jean, ${ }^{4}$ Caroline Larue, ${ }^{1}$ Lily Lessard, ${ }^{4}$ Luc Mathieu, ${ }^{5}$ Jacinthe Pépin, ${ }^{1}$ Mélanie Perroux, ${ }^{1}$ Aurore Cockenpot ${ }^{1}$}

To cite: Contandriopoulos D, Duhoux A, Roy B, et al. Integrated Primary Care Teams (IPCT) pilot project in Quebec: a protocol paper. BMJ Open 2015;5:e010559. doi:10.1136/bmjopen-2015010559

- Prepublication history for this paper is available online. To view these files please visit the journal online (http://dx.doi.org/10.1136/ bmjopen-2015-010559).

Received 17 November 2015 Accepted 26 November 2015

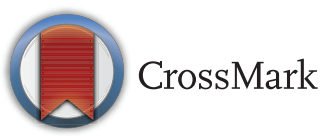

${ }^{1}$ Faculty of Nursing, University of Montreal, Montréal, Québec, Canada ${ }^{2}$ Faculty of Nursing, University of Laval, Québec, Québec, Canada

${ }^{3}$ Faculty of Medicine, University of Laval, Québec, Québec, Canada

${ }^{4}$ University of Québec in Rimouski, Rimouski, Québec, Canada

${ }^{5}$ University of Sherbrook, School of Nursing, Sherbrooke, Québec, Canada

Correspondence to Mélanie Perroux; melanie. perroux@umontreal.ca

\section{ABSTRACT}

Introduction: The overall aim of this project is to help develop knowledge about primary care delivery models likely to improve the accessibility, quality and efficiency of care. Operationally, this objective will be achieved through supporting and evaluating 8 primary care team pilot sites that rely on an expanded nursing role within a more intensive team-based, interdisciplinary setting.

Methods and analysis: The first research component is aimed at supporting the development and implementation of the pilot projects, and is divided into 2 parts. The first part is a logical analysis based on interpreting available scientific data to understand the causal processes by which the objectives of the intervention being studied may be achieved. The second part is a developmental evaluation to support teams in the field in a participatory manner and thereby learn from experience. Operationally, the developmental evaluation phase mainly involves semistructured interviews. The second component of the project design focuses on evaluating pilot project results and assessing their costs. This component is in turn made up of 2 parts. Part 1 is a pre-and-post survey of patients receiving the intervention care to analyse their care experience. In part 2, each patient enrolled in part 1 (around 4000 patients) will be matched with 2 patients followed within a traditional primary care model, so that a comparative analysis of the accessibility, quality and efficiency of the intervention can be performed. The cohorts formed in this way will be followed longitudinally for 4 years.

Ethics and dissemination: The project, as well as all consent forms and research tools, have been accepted by 2 health sciences research ethics committees. The procedures used will conform to best practices regarding the anonymity of patients.

\section{INTRODUCTION}

Healthcare systems in all wealthy countries are facing significant challenges: changes in demographic structure, increasing prevalence of chronic diseases, wide-scale deployment of expensive technology, alignment of available human resources to the needs of the population and shrinking government tax bases are a few examples. ${ }^{1-8}$
To achieve significant improvements in healthcare system performance, strengthening the primary care network appears to be especially key. $^{8-14}$ Moreover, every public commission that has studied the future of Canada's healthcare system has recommended making primary care a priority. ${ }^{15-21}$ Primary care is here defined according to Institute of Medicine as "the provision of integrated, accessible healthcare services by clinicians who are accountable for addressing a large majority of personal healthcare needs, developing a sustained partnership with patients, and practicing in the context of family and community." 9

The functioning of an efficient health system depends, to a large extent, on its ability to establish a continuum of care within which the role of primary care is to provide quality care that is accessible and efficiently delivered. 182223 However, reports on the accessibility of primary care show with remarkable consistency that delivery mechanisms currently in place in Canada have not been up to the joint challenges of accessibility and efficiency. $^{5-7}$ 24-29 All agree on the need to improve current primary care service offerings in Canada and Quebec, ${ }^{73}$ and many convergent data suggest that much could be done to push the interdisciplinarity, composition and work of primary care teams much further. ${ }^{23} 31-$ 36 In particular, increasing the scope of nursing practice is likely to improve accessibility of care and efficiency of delivery. ${ }^{37-48}$

However, although interdisciplinary teams incorporating an enhanced nursing role have strong potential, there are many practical challenges. Such an approach involves redefining professional boundaries and revisiting existing care models and organisational arrangements. ${ }^{49-54}$ The aim of the present project is to generate empirical knowledge on these topics.

Specifically, the overall aim of the project is to develop knowledge that is robust 
(internal validity), contextual (external validity) and useable (accessibility) on efficient implementation processes and effective advanced primary care nursing practice models. From its inception, this project has been developed in partnership with the Ministry of Health and Social Services (MSSS), the relevant regional Agencies, the Centre de santé et de services sociaux (CSSS), the Family Medicine Groups (FMGs) and other local partners operating in the territory (municipal authorities, citizen groups, etc).

\section{KNOWLEDGE REVIEW}

As far as scientific knowledge is concerned, there is a paradox, in that important research has been devoted to several themes-such as the practice of nurse practitioners, interprofessional collaboration and highperforming primary care models-generating robust knowledge, yet there are very few study results that can be used to establish functional operating parameters to support implementation of interdisciplinary primary care teams. The following paragraphs summarise the existing literature concerning a few themes that are central to this project.

\section{Characteristics of high-performing primary care models}

Following Shortell et $\mathrm{al}^{55}{ }^{55}$ we define performance as a combination of four elements: (1) accessibility, (2) quality of care, (3) efficiency, and (4) managerial and administrative learning capacity. The conceptual performance model and its subcomponents are illustrated in figure 1 .

Here, we refer to Donabedian ${ }^{56}{ }^{57}$ in defining accessibility as the alignment between structures of production, on the one hand, and society's needs and their geographic distribution, on the other. The definition of quality used here is adapted from the work on operationalisation of primary care quality measures conducted by the teams of Pineault, Beaulieu, and Haggerty. ${ }^{58-61}$ Quality of care is defined as the intersection of technical quality, continuity and comprehensiveness. Technical quality, in turn, can be broken down into three parts: the quality of the service, the appropriateness of care and the quality of communication. Continuity is defined, following Haggerty $e t a l,{ }^{60}$ as a patient being treated by a same professional or a same team over the course of time (relational continuity) and the delivered care being seamlessly coordinated (management continuity). Integrated care and services refers, on the one hand, to the care offered by Integrated Primary Care Teams (IPCTs), wherein medical care, nursing care, social care, healing practices and preventive practices all tie into each other smoothly, in a harmonious way that is optimal and sustained over time (horizontal integration) and, on the other hand, coordinated among different levels of services (vertical integration). ${ }^{61-63}$ Finally, comprehensiveness refers to a care structure being able to respond in an integrated way to all of patients' needs. Comprehensiveness has two dimensions: taking into account all of a patient's needs (whole person focus) and offering a complete basket of services (scope of services).

Efficiency is here defined, with reference to Brousselle $e t a l,{ }^{64}$ as the ratio between the quality of care and the use of resources. This definition represents technical efficiency, the aim of which is to reduce costs for a given result.

Finally, the implementation of organisational, administrative and clinical practices enabling the efficient

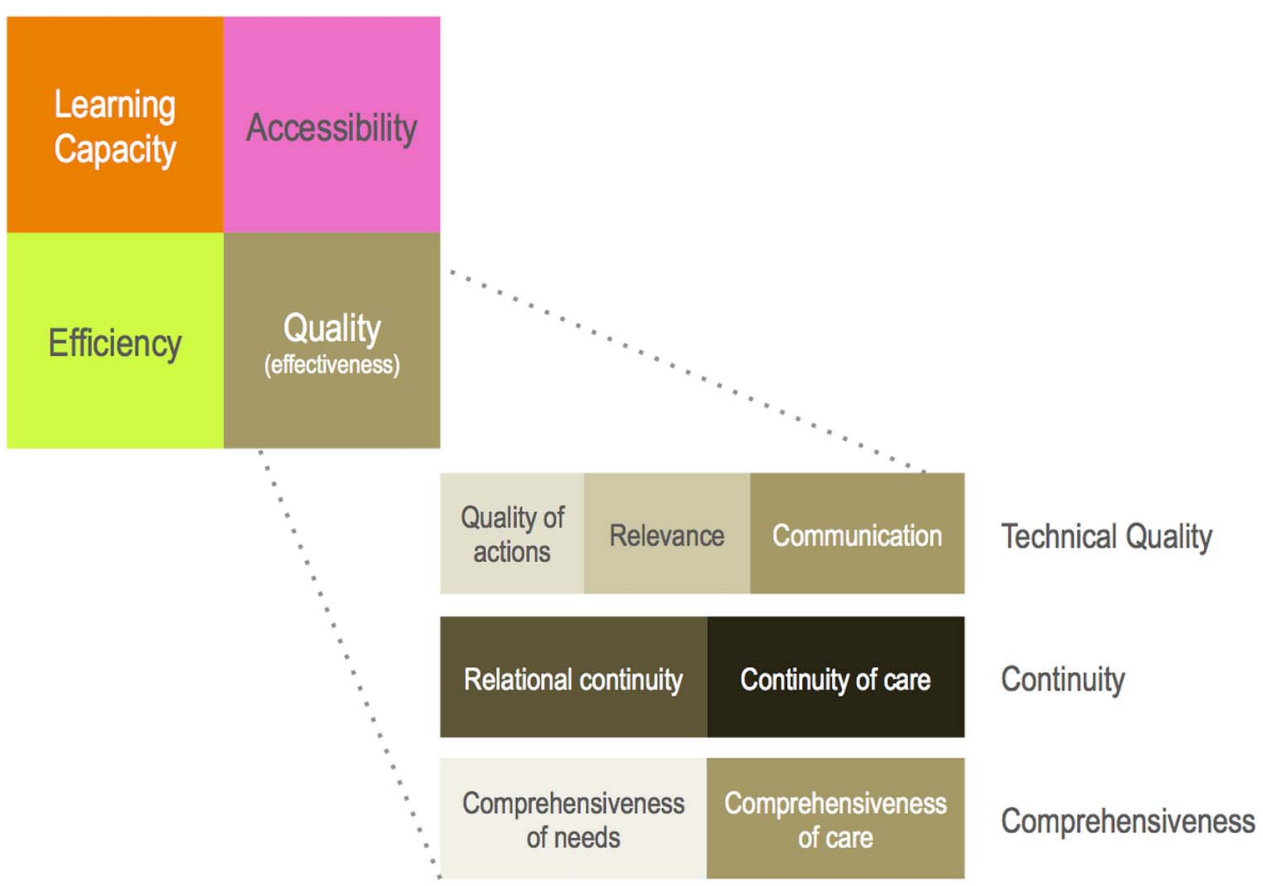

Figure 1 Conceptualising performance. 
production of quality care adapted to patients' preference requires a considerable learning capacity at the system and organisation levels.

There is tension between some aspects of performance as it is defined here (eg, practices such as drop-in clinics promote accessibility at the cost of continuity). However, by analysing the performance of primary medical clinics in Quebec, ${ }^{30} 626566$ we can identify operational parameters associated with high performance: schedules and appointment systems, team sizes, percentage of drop-ins, etc. ${ }^{67-70}$ Moreover, several convergent sources suggest that making greater use of advanced nursing practice could help improve accessibility, quality and efficiency of care delivery.

\section{Advanced primary care nursing practice}

There are three empirical data sources in Canada that suggest that increased participation of nurses and other health professionals practising the full range of their competencies could improve primary care delivery. The first stems from observations made in isolated rural communities where nurses, social workers and community workers, working out of dispensaries, have been for years delivering accessible and continuous primary care service in a particularly efficient way. ${ }^{71-75}$ Although very few studies have documented the care offered in dispensaries, the available data suggest that the accessibility, continuity and comprehensiveness of the care they provide is generally quite good. ${ }^{76-78}$ The second source of data derives from the results of analysis of various nurse practitioner deployment projects across the country. Nurse Practitioner-Led Clinics (NPLCs) in Ontario are clinics where nurse practitioners, in collaboration with physicians and other health professionals, autonomously manage primary care for a broad clientele. The aim is to provide primary care focused on continuity and comprehensiveness, while improving accessibility for patients who do not have access to a family physician. The results from a first NPLC pilot project in Sudbury showed excellent patient satisfaction and positive perception by professionals. ${ }^{79}$ The NPLC deployment plan, supported by the Ontario Ministry of Health and Long-Term Care ${ }^{80} 81$ is currently projected to be carried out over several years. There are similar projects throughout Canada, and studies on these models have observed better use of care (fewer emergency room visits, greater interdisciplinary collaboration fostering continuity, improved patient satisfaction and ability to make decisions regarding their own care, and increased satisfaction among health professionals). ${ }^{34} 8283$ Finally, similar structures have been established in the USA since the scope of nurse practitioner practice was expanded in 1997, most based on interprofessional practice. ${ }^{83}$

The third source of data on nurses' contribution to primary care delivery consists of studies on the effectiveness of care provided by primary care nurse practitioners (PCNPs). Systematic reviews of the quality of the care provided by PCNPs have been conducted in primary care $^{84-86}$ and in dermatology. ${ }^{87}$ Moreover, a comprehensive review of Canadian and international literature turned up 28 randomised studies that evaluated the effectiveness of care provided by PCNPs. ${ }^{51}$ These studies were conducted among elderly patients living in the community ${ }^{88} 89$ or among a general clientele suffering from chronic disabilities or diseases. ${ }^{90-95}$ Studies were also carried out in rural areas ${ }^{41} 96$ to better understand the specific needs of that population. The results of all these studies converged and showed that PCNPs improved care for patients with a chronic condition. Few studies looked at the impact on costs of using enhanced nursing practice. ${ }^{97} 98$ Likewise, there are only a few studies focused on defining the role and contributions of PCNPs. Although there seems to be an interest at the international level in increasing the role of primary care nurses, ${ }^{99}$ there has been little work done to conceptualise their role or to analyse the effects of their interventions. A few studies have shown that, after brief but targeted training, nurses could autonomously take over treatment for a great majority of the pathologies commonly managed in primary care. ${ }^{100-102}$ These studies show that the quality of care and patient satisfaction are both high. Other studies ${ }^{103}{ }^{104}$ have demonstrated not only the need to provide public education on the role of nurses to improve patient acceptance, ${ }^{105}$ but also the need to train nurses, especially with regard to pharmaceuticals. ${ }^{99}$

\section{Collaboration and redrawing professional boundaries}

Despite convergent evidence that interdisciplinarity can be pushed much further within primary care teams, the processes by which professionals collectively redraw professional boundaries, their specific involvement in treatment, and the mechanisms for collaboration are not clear. ${ }^{51} 98106$ Thus, the deployment of nurse clinicians and then of PCNPs in FMGs in Quebec has shown that the capacity for implementing well-organised and effective interprofessional collaboration models can vary significantly by setting. ${ }^{65} 107 \quad 108$ At a logical level, distributing work based on the principle of subsidiarity (which states that a task should be delegated to the lowest level competent enough to complete it) means reserving physicians' competencies for complex tasks and entrusting common problems to other professionals. In practice, however, there is quite a lot of overlap between the areas of practice of physicians, PCNPs and nurse clinicians. How roles, scopes of practice and contributions of individual professionals are determined depends in large part on the consensus established among the different professionals, ${ }^{109}$ assisted by clear guidelines and care protocols, as well as by formal and informal consultation and referral mechanisms. ${ }^{31}{ }^{110-113}$ The literature suggests that clarity of roles and quality of communication between the stakeholders are core factors facilitating this process. ${ }^{34} 53114115$

Beyond local factors over which professionals have direct control, regulatory and legal factors also play a 
critical role in the development of collaboration. 4951110116 The majority of primary care in Quebec is delivered in very autonomous production structures, under the direct control of the physicians who practice there, with physicians being remunerated on a fee-for-service basis and other professionals being salaried. ${ }^{61} 117118$ In contrast, the deployment settings being considered for IPCTs vary considerably in this respect. At one end of the spectrum are local community health centres (CLSCs), where there is not much fee-for-service care; these are public structures with fairly clear external governance. At the other end, private practices registered as FMGs are characterised mainly by a fee-for-service model in private premises, with very autonomous governance. The influence of macrosystemic factors on the implementation processes and the nature of the practice models being implemented are integral parameters to be considered when developing the operational modalities for the pilot projects.

\section{METHODS AND ANALYSIS}

\section{Interventions to be measured: interprofessional primary} care teams

As presented in the introduction, the objective of this proposal is to fund analysis of the implementation and evaluation of eight IPCT pilot sites with characteristics that are significantly different from most primary care structures currently available in Canada. The pilot IPCT sites are primary care structures that aim to respond, through a team-based approach, to all the routine needs of registered patients. Routine needs include prevention, primary care and coordination of services.

The IPCT care model is based on an intensive interdisciplinary practice implemented according to the principle of subsidiarity; on an advanced nursing practice with an expanded role; and on the principle of group practice. According to results obtained in other contexts, a majority of primary care needs does not require the intervention of a physician. ${ }^{39}$ Furthermore, by group practice we mean that the interdisciplinary IPCT team jointly treats all patients, sharing resources as well as responsibilities. Thus, patients are registered with the clinic and not with a particular practitioner, which is consistent with best practices in the field. ${ }^{79}$ In the terms of workforce, the teams should mainly consist of nonphysicians (nurses, PCNPs, nutritionists, social workers, etc). The available data suggest that physician/nurse full-time equivalent (FTE) ratios of 1 to 1 or even 1 to 2 are realistic for primary care teams that have an important prevention/promotion role.

From an operational standpoint, the IPCTs will be set up in four health regions of Quebec in collaboration with several partners. In identifying potential pilot sites and IPCT parameters, the individual priorities, resources and constraints of each partner site were key. Thus, the team compositions and the characteristics of the care model vary by setting. Depending on the pilot site, the nursing workforce ranges from 0 to 4 PCNP FTEs; from 1 to 4 clinical nurse FTEs (bachelor-level training); and from 0 to 3 technical nurses (college-level training). The medical workforce ranges from 1 to 9 physicians, corresponding to 0.5 to 4 FTEs. The rest of the workforce consists of social workers (0 to 1 FTE), pharmacists, respiratory therapists, occupational therapists, psychologists and other health professionals. Some sites have a significant training role. The anticipated number of patients to be followed ranges from 1400 to 7750 per site (average 3150, median 2775, total 25 200). The sites also vary considerably in terms of legal structure, from CLSCs $(n=1)$, to FMGs $(n=3)$, a non-profit organisation $(\mathrm{n}=1)$ and a family medicine unit $(\mathrm{n}=1)$. The sites selected for the project demonstrated both a willingness to participate and strong potential for change focused on implementing advanced nursing practice. Since funding for nursing positions is provided by the CSSSs, the selected sites also needed to be able to fund or reallocate resources.

The aim of the IPCT model is to improve primary care delivery performance and, more specifically, to simultaneously optimise accessibility, quality and effectiveness of the care being delivered. ${ }^{60} 119$ The first IPCT objective is to offer wide accessibility. Our hypothesis is that there is currently a significant volume of basic routine healthcare needs that are not being treated or that are cared for too late due to difficulties in accessing primary care. Setting up a primary care structure that is geographically close, easy to access and focused on routine care, should, in our opinion, improve accessibility, better respond to needs and ultimately improve the health of the population served. The IPCT model also focuses on optimising quality of care (technical quality, continuity and comprehensiveness). The IPCT teams have a mandate to optimise continuity of care by coordinating the totality of care for the patients being treated, including diagnostic services and specialised care offered in hospital. The objective is to maximise IPCTs' potential as an entry point for access to all of the care offered by CSSSs and, if need be, by their partner hospitals. Likewise, one of the strengths of the dispensary model that exists in remote areas is the relational continuity between the clientele and the health professionals working there. As dispensaries are often the only care structure available, ${ }^{71}$ in many remote areas there is de facto relational continuity, even when the clientele is not registered and services are offered without appointment. The IPCT model must be developed in a way that reproduces this relational aspect, which means focusing on a population identified through a registration process. Such registration will enable the care team to personalise care. Drop-in services could still be offered to the general public, but patients seen through this route would then be registered. The IPCT model is also aimed at improving the comprehensiveness both of care and of the response to needs, from promotion and prevention to palliative care and, in particular, to anchoring the 
management of chronic disease and mental health. This comprehensiveness will help, among other things, to diminish the dichotomy between treatment of physical and mental health. In this respect, the approach is completely in line with provincial strategies in this field. ${ }^{120-122}$ Providing care for chronic disease, including mental disorders, calls for advanced clinical expertise at the initial diagnosis and treatment plan stage, as well as sustained day-to-day care management. The IPCT model is based on a collaborative model ${ }^{123}$ for chronic illness care. In fact, for several common chronic diseases, this approach will be facilitated by the current implementation, in Quebec, of multisectoral interventions to act on their determinants and of group prescriptions for medications and tests.

More specifically, the project aims to answer three main research questions.

- What are the most appropriate clinical and organisational structures for IPCTs to offer integrated care to a general clientele?

- How do we support professionals in transforming their practices and in developing an interdisciplinary and collaborative care model?

- What are the effects of IPCTs on (a) accessibility; (b) efficiency; and (c) quality, including the dimensions of (i) technical quality, (ii) continuity and (iii) comprehensiveness of care.

\section{Research design}

The pilot projects will be evaluated according to a design based on structured mixed methods, consisting of two components. The first is an implementation analysis using the formative approach of developmental evaluation. ${ }^{124-126}$ The second component is an analysis of the effects of each pilot project. ${ }^{127}$ The overall evaluation approach is founded on the conceptual quality model proposed by Donabedian. ${ }^{56}$ The aim of the implementation analysis component is to understand the mechanisms that link structures to processes and to results in each pilot project, so that both processes and structures can be optimised to obtain the target results. A mixedmethod design (quantitative/qualitative and precohort/ postcohort) is used to strengthen the validity of results through triangulation.

\section{Component A: analysing implementation of interprofessional primary care teams}

The implementation analysis will be conducted in two interdependent parts. The first is a logical analysis and the second is a case analysis using a developmental approach. The general objective of this component is to support implementation of an efficient care model in each of the pilot sites by collaborating with the relevant clinical teams and CSSSs. The logical analysis part will identify scientific data that are useful for implementation and express them dynamically in terms of each site's operational objectives. The developmental evaluation part will support local teams in transforming and developing the practice model.

\section{Part 1: logical analysis}

Logical analysis ${ }^{128}$ and more specifically reverse logical analysis, ${ }^{129}$ is based on interpreting available scientific data in such a way as to understand the causal processes by which the objectives of the intervention being studied may be achieved. In other words, what interactions among the institutional, structural, organisational or clinical elements analysed in other contexts would explain the effects obtained? This analysis identifies fundamental causal hypotheses linking intervention characteristics with the implementation conditions required to achieve the target objectives, while grounding those hypotheses in scientific knowledge (maximising internal validity).

Two data sources will be used at the logical analysis stage. The first comes from a previous project funded by Canadian Institutes of Health Research that concerns the deployment of PCNPs in Quebec ${ }^{130}$ and, more specifically, interdisciplinary collaboration between physicians and PCNPs, the efficiency of primary care offered by PCNPs, and clinical support processes. The second source of data consists of a scoping literature review $^{131} 132$ on primary care models, which will be conducted at the outset of the project. The team has a highly developed expertise in both the conceptual and methodological aspects of this field. ${ }^{133-135}$

\section{Part 2: developmental evaluation}

There is no published data that can shed light on exactly how the causal processes identified in the above logical analysis ${ }^{128}$ fit in with the specific priorities, characteristics and resources of each pilot site. In practice, each context is strongly shaped by the specific details of the institutions, organisation and individuals involved. To strengthen the external validity of our proposed recommendations, we will also perform implementation analyses in the settings where the IPCTs will be deployed. The type of implementation analysis we have selected is developmental evaluation, ${ }^{124-126}$ the aim of which is to support teams in the field in a participatory manner, helping them develop an efficient practice model and thereby learn from experience. Developmental evaluation is a formative evaluation approach $^{136137}$ designed to enhance an intervention in progress: "Developmental evaluation supports innovation development to guide adaptation to emergent and dynamic realities in complex environments" ${ }^{124}$ In contrast to summative approaches, which assess the achievement of an intervention's objectives after the fact, formative approaches allow for an intervention to be adjusted and are therefore especially relevant when implementing complex interventions. ${ }^{126} 136$ A feature of developmental evaluation is the high level of collaboration and feedback in real time between the evaluation team and the team implementing the intervention. This 
approach is clearly inspired by the bottom-up perspectives of implementation research. ${ }^{138-146}$ The main idea is that, in complex interventions, ${ }^{124} 125$ only the team in the field has access to all the information and levers needed to get the most out of the intervention. In such a situation, rather than trying to determine precise implementation parameters a priori in a centralised way, the intervention implementation should balance, on one hand, the clarity of the implementation objectives and parameters and, on the other, the freedom to adapt to the local setting. In the context of our project, the aim is support the teams on site and facilitate rapid feedback, so that diagnoses and solutions can be refined and tested. Developmental evaluation's participatory approach bears some similarity to a consulting relationship, wherein the research team's expertise serves to support the IPCT implementation sites and to help develop efficient care models. Moreover, in this way, knowledge is produced by the direct involvement of the research team in the processes being analysed.

Operationally, the developmental evaluation phase mainly involves semistructured interviews (both individual and group), participant observation, ${ }^{147}{ }^{148}$ and support for clinical practice. At the beginning of the project, meetings will be held with clinicians and administrators in the care teams and CSSSs involved in each pilot site. For each site, there will be on average 3 interviews at the CSSS level, and 4-5 individual or collective interviews at the clinical team level, for a total of about 70 interviews across the eight sites. The purpose of the semistructured interviews is, among other things, to finetune the wording of specific objectives for each site, identify possible divergences, identify the care structures and processes as well as the characteristics of the target care models, and establish the extent of current practice and the transformations required. The data will then be analysed both by site and cross-sectionally to build a profile of each site at time 0 and to do an operational modelling of the intended model and its capacity to respond comprehensively to all the needs. The interview texts will be analysed and processed using discourse analysis techniques. ${ }^{149-153}$ The research team has significant expertise in using these theoretical and methodological tools. The data will be integrated with the logical analysis results and used to establish a set of recommendations to support the implementation process for the new model in each site. This initial result will be presented to the participants at each site in a group work meeting and discussed collegially. Thereafter, the procedures for data collection through interviews will be adjusted according to individual site needs, while collaboration to monitor the transformation will mainly take the form of participant observation. The operational change process at each site will be led by the CSSS and the local team, but the research team's involvement will support the process by supplying external expertise, facilitating crosssite learning, and providing clarification based on evidence drawn from logical analysis.
Two strategies will guide clinical practice support in the study pilot sites during the implementation phase. The first strategy will be to set up a virtual professional practice community for clinicians at the pilot sites. ${ }^{154-156}$ This community is founded on principles expressed by Wenger et $a l,{ }^{157} 158$ pioneers of the concept of practice community: sharing of scientific and experiential knowledge, and creation of a collective body of knowledge through regular interaction. We foresee discussion and exchange on the following themes: (1) definition of roles at pilot sites; (2) scope of practice for enhanced roles; (3) competency development needs for advanced practice; and (4) practice transformation at sites, as research progresses. This virtual practice community will also be a tool for knowledge transfer and sharing over the duration of the project (see section 5.3). The second support strategy will be to provide interactive learning capsules that convey the possible scope of nursing competencies, addressing both expanded roles and advanced practice, according to the needs expressed. Nurse clinicians and PCNPs could be called on to help prepare these capsules.

In addition to supporting and advancing implementation, this research component also has the objective of producing generalisable scientific knowledge on the IPCT practice model implementation process and on site characteristics. Specifically, the qualitative data collected will be used to assess each site's organisational learning capacity. To this end, interview and observational data will be analysed from a 'procedural' point of view, ${ }^{159} 160$ in the sense that we will seek to identify the logical links between sequences of events. To ensure the reliability of results, we will use two analysis strategies concurrently: a narrative analysis strategy ${ }^{161} 162$ and a graphic analysis strategy. ${ }^{163}$ Employing two complementary methods of analysis in this way (methodological triangulation) will help improve the reliability of results. ${ }^{148} 164$

\section{Component B: analysing the effects of IPCTS}

The second component of the design is a quantitative evaluation of the effects of the IPCTs following a quasi-experimental longitudinal design. This component is in turn made up of two parts. Part 1 is a pre-and-post survey of patients receiving IPCT care to analyse their care experience. In part 2, each patient enrolled in part 1 will be matched with two patients followed within a traditional primary care model, so that a comparative analysis of the accessibility, quality and efficiency of IPCTs can be performed. The cohorts formed in this way will be followed longitudinally for 4 years. Figure 2 presents the design structure.

The contribution of both components and of their respective parts to measuring the various dimensions of IPCT performance is presented in table 1 below.

\section{Time framework of the design}

The date on which the first patient registers with an IPCT (see section 5.2.2) will constitute t0. The 


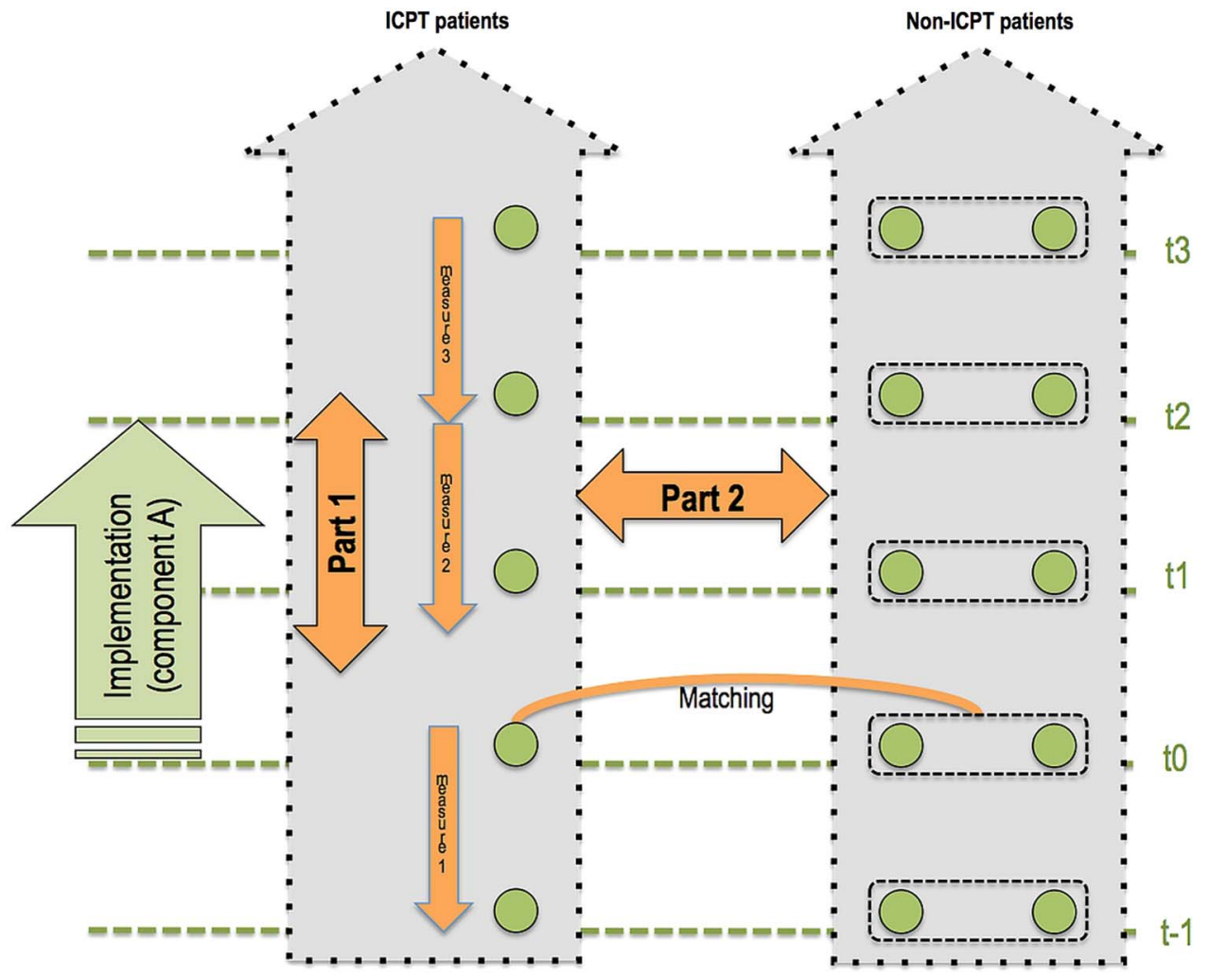

implementation phase (component A of the project) will take place over 2 years $(\mathrm{t} 0-\mathrm{t} 2)$. The patients followed in IPCTs who will have agreed to participate in the study will be surveyed at three points in time ( $\mathrm{t} 0, \mathrm{t} 2$ and $\mathrm{t} 3$ ) regarding their care experience over the previous year. The medical-administrative data used to follow the cohorts in part 2 will be obtained for $\mathrm{t} 1-\mathrm{t} 3$, that is, for four whole years.

\section{Study populations and sample}

First cohort (part 1): All the patients consulting an IPCT will be invited to 'register' with the team for follow-up (dummy rostering). Those doing so will form the study population. On registering with the IPCT, patients will be invited to participate in the research project, and informed consent will be requested to authorise access to their medical-administrative data. We anticipate that at least 500 patients per IPCT will agree to participate in the study. They will form a cohort of around 4000 patients.

Second cohort (part 2): Each patient in the first cohort will be matched with a patient registered with a family physician, as understood by the Régie de l'assurance maladie du Québec (RAMQ), and with a patient not registered with a physician, who will together form a second cohort. For this, a request for access to information will be submitted to the Commission d'Accès à l'Information. The matching will be based on five criteria: patients' region of residence, age, sex, level of socioeconomic deprivation and chronic disease profile. In the medical-administrative databases, certain chronic diseases (eg, diabetes, hypertension, respiratory diseases, depression) are easy to identify using the RAMQ 'vulnerability' flag as well as algorithms developed by the Manitoba Center for Health Policy and Research and adopted by the Quebec National Institute of Public Health and the Population and Health services team of the Public Health Directorate of the Montreal Health and Social Services Agency. ${ }^{165-167}$

\section{Data sources}

Part 1: care experience of IPCT patients: This part is based on data collected through a questionnaire given to patients newly registered with an IPCT. The questionnaire will first be completed at the time of registration ( $\mathrm{t} 0$ ) and will cover patients' experience of care and their unmet meets during the year preceding registration $(\mathrm{t} 1-\mathrm{t} 0)$ as well as their current state of health. The same tool will be used to measure their experience of IPCT care at the end of the implementation phase (t2) and 1 year after the teams become functional ( $t 3)$. The questionnaires, which take about 30min each, will incorporate validated tools for measuring five components of IPCT performance. ${ }^{60} 59119168$ The tools will be adapted, so that the wording of the questions reflects the interdisciplinary nature of the team.

Part 2: comparative analysis of care trajectories: The second part involves combining five administrative databases to conduct a longitudinal follow-up of the use of services by a general clientele in Quebec. These databases are: (1) the RAMQ billing database, which tracks all medical services billed by physicians to the RAMQ except for 
Table 1 Operationalisation of variables and assessment of the components of performance

\section{Component A-analysing} implementation

\begin{tabular}{ll}
$\begin{array}{l}\text { Dimensions of } \\
\text { performance }\end{array}$ & Part 2 \\
\hline Learning capacity & $\begin{array}{l}\text { Qualitative assessment using } \\
\text { interview/observation data }\end{array}$ \\
Accessibility &
\end{tabular}

Accessibility

Efficiency

Quality

Technical quality

Continuity

Comprehensiveness

Outcomes

Health status

CCHS, Canadian Community Health Survey; CPCI, Components of Primary Care Index; IPCT, Integrated Primary Care Team; PCAS, Primary Care Assessment Survey; PCAT-s, Primary Care Assessment Tool-short Form; SF-12, Short-Form Health Survey 12-items; VANCOSS, Veterans Affairs National Outpatient Customer Satisfaction Survey.

services performed by salaried physicians. In Quebec, around $4 \%$ of physicians are paid mainly by salary, and services provided under this remuneration model represent around $3 \%$ of the volume of primary care services; ${ }^{118}$ (2) the I-CLSC database, which records all services provided at CLSCs in Quebec; (3) the Med-ECHO database, which tracks all hospital episodes; (4) the pharmaceutical services database, which compiles services provided to persons registered with the public drug insurance plan; and (5) the all patients refined - diagnosis related groups (APR-DRG) database, which records the 'relative intensity level of resources used' (niveau d'intensité relative des ressources utilisées -NIRRU) for all hospital stays and provides a means of

\section{Component B-analysing effects}

Part 1

Part 2

PCAT-s First-Contact Access subscale ${ }^{179-180}$ and Statistics Canada (CCHS) questions on unmet needs

Quality of communication between professionals and patients according to the $\mathrm{CPCl}$ Interpersonal Communication scale ${ }^{58181}$ Continuity of care, based on the VANCOSS. ${ }^{59}{ }^{184}$ The selected tool allows us to assess both components of continuity described earlier $^{185}$

Relational continuity, assessed using the PCAS Contextual knowledge subscale ${ }^{186187}$

Comprehensiveness of care, based

Proxy: relative change in volume of care between the two groups, with the hypothesis that, for IPCT patients, the volume of primary care will increase and the volume of emergency and specialised ambulatory care will decrease

Relative costs of the care trajectories of each of the two cohorts

Set of indicators drawn from the works of Katz et al 2004 and Tousignant et al

Continuity of care based on indicators drawn from the work of Tousignant et al $2005^{183}$

Relational continuity (proxy) for IPCT patients and registered non-IPCT patients, proportion of care received from the physician/ group seen at registration. $2005^{182183}$ 
The economic cost of care trajectories will be assessed by totalling for each year and each patient (1) the cost associated with each hospital stay (calculated based on the NIRRU ${ }^{169}$ ) and (2) the costs of non-hospital medical services used by patients, for which data are available in the medical-administrative databases or in the dummy billing for patients who are followed in an IPCT. The costs will be aggregated by care structure (IPCT and non-IPCT), so that we can analyse their evolution over the 4 years of monitoring for the patients in both cohorts. This method will not provide fine details of the allocation of fixed costs for each episode (ie, the portion of fixed costs in an establishment's budget, ie, attributed to a specific care episode). On the other hand, since the analysis relies on comparing the average cost of each cohort, this limitation has no effect on the validity of the indicator.

\section{Analyses}

Part 1: Descriptive analyses will be performed on the whole sample and will be stratified by IPCT. To determine whether being followed in an IPCT led to a change over time in terms of accessibility and quality of services, and in patients' health status, we will use linear generalised estimating equations. Time will be added to the model as an explanatory variable, and we will control for individual characteristics of patients. Once the main model is constructed, we will evaluate possible interactions, with a particular focus on the specific effects of each IPCT.

Part 2: For this part, in addition to the descriptive analyses, we propose to use two complementary methods: propensity scores (PS) and differences-in-differences (DD). Both of these methods have been widely used to measure the impact of healthcare system factors on results. ${ }^{170-172}$ PS provides a means of weighting individuals, so that matched cohorts can be compared. ${ }^{170}$ Weighting coefficients are calculated probabilistically based on the five criteria used to match patients and on the data available concerning the use of health services during the period preceding registration. The DD method provides a way of comparing changes in accessibility, efficiency and quality between IPCT and non-IPCT patients over a 4-year period. This method relies on the hypothesis that confounding factors will be accounted for by selecting a matching and comparable control group. DD regression models will be developed for each dependent variable being studied (volume of services, costs, etc). The data will be grouped into four periods of 12 months, so that changes over time can be evaluated. The weighting coefficients derived from the PS will be used in each DD model. Our sample is large enough that analyses can be stratified for each of the eight IPCTs, which will help us evaluate the differences between sites. All statistical analyses will be performed using STATAV.13 software.

\section{ETHICS AND DISSEMINATION}

The project, as well as all consent forms and research tools, have been accepted by the University of Montreal
Health Sciences Research Ethics Committee (CERES) and the Research Ethics Committee of the Centre de Santé et de Services Sociaux de la Montagne. Furthermore, administrative data for the control patients will be obtained through a request to the Commission d'Accès à l'Information du Québec. The safeguards for protecting the anonymity of patients outside of the IPCTs will be examined by the Caisse d'Accès à l'Information, and the procedures used will conform to best practices in the field.

All personal information collected during the course of the study will remain confidential and anonymous. The computer in which the data will be entered will be password-secured, and all data will be encrypted with specialised software. All paper documentation that could reveal patients identity (such as the consent form) will be kept under lock in the office of the principal investigator. The research data will be kept for a period of 7 years after the end of the project. The nominative data (including email addresses and telephone numbers) will be kept for about 3 years (until the end of the follow-up period) and then will be destroyed in a secure way.

This project includes an important component focused on integrating results and making them available. To begin with, we will review knowledge produced from the implementation analysis (Component A) and the effects analysis (Component B) to understand how (1) the implementation process and (2) the individual characteristics of the sites influenced the observed effects. This will then help us develop a formal recommendation on functional implementation parameters for an interdisciplinary primary care model and on how they influence potential effects.

As the project components are completed, dynamic knowledge transfer interventions will be set up to help incorporate results into decision-making and practices in the field. The team's previous work on analysing knowledge transfer and using evaluation results will serve as a conceptual structure to support the interventions. ${ }^{133-135}$ 173-175 More specifically, the proposed interventions are based on the observation that the steady increase in knowledge transfer efforts combined with pressure to improve the efficiency of clinical and organisation practice leads to an widening gap between the volume of information available and the capacity to make use of it (time, attention, skills, etc). ${ }^{173}{ }^{176-178}$ Therefore, the objective is not to transfer more information, but rather to sort, synthesise and contextualise it, and then to target users and adapt transfer processes. In other words, it is a matter of matching needs, data and knowledge users more efficiently. To do this, several initiatives will be undertaken. First of all, the virtual practice community set up as part of Component A will be used as a platform for exchange between people on the ground at each pilot site (clinicians, administrators, research professionals, researchers, trainers, etc). ${ }^{154} 157158 \mathrm{~A}$ meeting with all participants at the implementation halfway point will also serve to step up cross-site learning. Furthermore, we will make use of 
ongoing collaborations with several project stakeholders (Ministry of Health and Social Services, professional corporations, Faculties of Nursing, Medical Board of Québec), as well as with partners involved in other ongoing projects to disseminate information to the target audiences. Popularised summaries of the results will be submitted for publication in professional journals and electronic newsletters. We will also offer tailored presentation workshops to people playing key roles in incorporating the results into practice. Finally, following usual practice, the results will be presented at scientific conferences and published in high-calibre international journals.

Twitter Follow Isabelle Brault at @ibrault, Luc Mathieu at @LucMathieu1, Mélanie Perroux at @chairepocosa, Damien Contandriopoulos at @faussenurse and Arnaud Duhoux at @ArnoDuh

Contributors $D C$ and $A D$ conceived of the study, drawn its design and coordination, carried out the study, found the case and drafted and review the study protocol. MP participated in all these steps. BR participated in the design of the study, found a case and reviewed the study protocol. LL, IB, EJ, $\mathrm{MA}, \mathrm{CL}$, J-PB, C-AD, JP, CD, FG, LM, RBDS and AC participated in the design of the study and reviewed the study protocol. All authors read and approved the final manuscript.

Funding This research is funded by the Canadian Institutes of Health Research-Institute of Health Services and Policy Research.

Competing interests None declared

Ethics approval University of Montreal Health Sciences Research Ethics Committee (CERES) and the Research Ethics Committee of the Centre de Santé et de Services Sociaux de la Montagne.

Provenance and peer review Not commissioned; peer reviewed for ethical and funding approval prior to submission.

Open Access This is an Open Access article distributed in accordance with the Creative Commons Attribution Non Commercial (CC BY-NC 4.0) license, which permits others to distribute, remix, adapt, build upon this work noncommercially, and license their derivative works on different terms, provided the original work is properly cited and the use is non-commercial. See: http:// creativecommons.org/licenses/by-nc/4.0/

\section{REFERENCES}

1. Davis K. Learning from high performance health systems around the globe, invited testimony: Senate Health, Education, Labor, and Pensions Committee Hearing "Health Care for All Americans: Challenges and Opportunities". The Commonwealth Fund, 2007.

2. Evans RG. Fellow travelers on a contested path: power, purpose, and the evolution of European health care systems. J Health Polit Policy Law 2005;30:277-93.

3. Kotzian P. Control and performance of health care systems. A comparative analysis of 19 OECD countries. Int $J$ Health Plann Manage 2008;23:235-57.

4. Mechanic D. The truth about health care: why reform is not working in America (critical issues in health and medicine). Camden: Rutgers University Press, 2008.

5. Schoen C, Osborn R, Squires D, et al. A survey of primary care doctors in ten countries shows progress in use of health information technology, less in other areas. Health Aff 2012;31:2805-16.

6. Commissaire à la Santé et au bien-être. Perceptions et expériences des médecins de première ligne: Le québec comparé. Résultats de l'enquête internationale sur les politiques de santé du commonwealth fund de 2012. Québec: Commissaire à la Santé et au Bien-Être du Québec; Gouvernement du Québec, 2013.

7. Hutchison B. From hall to now: reflections on Canadian Medicare from a primary care perspective. 2013 Emmett Hall Memorial Lecture. Vancouver: Canadian Association for Health Services and Policy Research (CAHSPR), 2013.

8. Rittenhouse DR, Shortell SM, Fisher ES. Primary care and accountable care-two essential elements of delivery-system reform. N Engl J Med 2009;361:2301-3.
9. Donaldson MS, Yordy KD, Lohr KN, Vanselow NA, eds. Primary care: America's health in a new era (Committee on the Future of Primary Care, Institute of Medicine). Washington: National Academies Press, 1996. (http://www.nap.edu/catalog.php?record id $=5152$-toc)

10. Ham C, York N, Sutch S, et al. Hospital bed utilisation in the NHS, Kaiser Permanente, and the US Medicare programme: analysis of routine data. BMJ 2003;327:1257.

11. Macinko J, Starfield B, Shi L. The contribution of primary care systems to health outcomes within Organization for Economic Cooperation and Development (OECD) countries, 1970-1998. Health Serv Res 2003;38:831-65.

12. Starfield B, Yushi L, Macinko J. Contribution of primary care to health systems and health. Milbank Q 2005;83:457-502.

13. Studnicki J, Murphy FV, Malvey D, et al. Toward a population health delivery system: first steps in performance measurement. Health Care Manage Rev 2002;27:76-95.

14. McMurchy D. What are the critical attributes and benefits of a high-quality primary healthcare system? Ottawa: Canadian Health Services Research Foundation, 2009.

15. Commission Castonguay-Nepveu. Rapport de la Commission d'enquête sur la santé et le bien-être social. Québec: Éditeur officiel du Québec, 1967-1970.

16. Commission Clair. Rapport et recommandations de la commission d'étude sur les services de santé et les services sociaux: Les solutions émergentes. Québec: Gouvernement du Québec, 2000.

17. Commission Rochon. Rapport de la commission d'enquête sur les services de santé et les services sociaux. Québec: Publications du Québec, 1988.

18. Contandriopoulos D, Brousselle A. Reliable in their failure: an analysis of healthcare reform policies in public systems. Health Policy 2010;95:144-52.

19. Fyke KJ. Caring for Medicare: sustaining a quality system. Regina: Saskatchewan Commission on Medicare, 2001.

20. Ontario HSRC. Looking back, looking forward, seven points for action. Toronto: Ontario Health Services Restructuring Commission, 2000.

21. Romanow RJ. Building on values: the future of health care in Canada-final report. Ottawa: Commission on the Future of Health Care in Canada, 2002

22. Ginsburg JA, Doherty RB, Ralston JF Jr, et al. Public Policy Committee of the American College of Physicians. Achieving a high-performance health care system with universal access: what the United States can learn from other countries. Ann Intern Med 2008;148:55-75.

23. Baker GR, Maclntosh-Murray A, Porcellato C, et al. High performing healthcare systems: delivering quality by design. Books, Toronto: Longwoods Publishing Corporation, 2008.

24. Commonwealth Fund. 2012 Commonwealth Fund International Survey of primary care doctors. Washington, 2010. http://www. commonwealthfund.org/Surveys/2012/Nov/2012-International-Survey. aspx

25. Commissaire à la Santé et au bien-être. L'expérience de soins de la population: Le Québec comparé. Résultats de l'enquête internationale du commonwealth fund de 2010 auprès de la population de 18 ans et plus. Québec: Commissaire à la Santé et au Bien-Être du Québec; Gouvernement du Québec, 2011.

26. Commissaire à la Santé et au bien-être. L'expérience de soins des personnes présentant les plus grands besoins : Le Québec comparé. Résultats de l'enquête internationale sur les politiques de santé du commonwealth fund de 2011. Québec: Commissaire à la Santé et au Bien-Être du Québec; Gouvernement du Québec, 2012.

27. CFPC. The role of the federal government in Health Care. Mississauga: The college of famliy physicians of Canada, 2013.

28. Health Council of Canada. Better health, better care, better value for all: refocusing health care reform in Canada. Toronto: Health Council of Canada, 2013.

29. Direction de santé publique. Des économies réalisées grâce aux GMF: oui, mais...GMF sous les projecteurs. 2013;1(oct 2013).

30. Haggerty JL, Pineault R, Beaulieu M-D, et al. Continuité et accessibilité des soins de première ligne au québec : Barrières et facteurs facilitants. Montréal: Rapport de recherche, 2004. http:// www.irspum.umontreal.ca/rapportpdf/CH04-01f.pdf.

31. Bailey $\mathrm{P}$, Jones $\mathrm{L}$, Way $\mathrm{D}$. Family physician/nurse practitioner: stories of collaboration. J Adv Nurs 2006;53:381-91.

32. Bamford D, Griffin M. A case study into operational teamworking within a UK hospital. Int $J$ Oper Prod Manag 2008;28:215-37

33. Litaker D, Mion L, Kippes C, et al. Physician-nurse practitione teams in chronic disease management: the impact on costs, clinical 
effectiveness, and patients' perception of care. $J$ Interprof Care 2003;17:223-37.

34. Hasselback P. The Taber integrated primary care project: turning vision into reality. Canadian Health Services Research Foundation, 2003.

35. Bonsall $\mathrm{K}$, Cheater FM. What is the impact of advanced primary care nursing roles on patients, nurses and their colleagues? A literature review. Int J Nurs Stud 2008;45:1090-102.

36. Doherty RB, Crowley RA. Principles supporting dynamic clinical care teams: an American College of Physicians position paper. Ann Intern Med 2013;159:620-6.

37. Canadian Nurse Practitioner I. Nurse practitioners: the time is now. A solution to improving access and reducing wait times in Canada. Ottawa, ON: Canadian Nurse Practitioner Initiative, 2006. Report No.: 1-55119-826-6 Contract No.: Report.

38. DiCenso A, Matthews S. Report of the Nurse Practitioner Integration Task Team submitted to the Ontario Minister of Health and Long-Term Care. Toronto, ON: Ministry of Health and Long-Term Care, 2007. Contract No.: Report.

39. Laurant M, Reeves D, Hermens R, et al. Substitution of doctors by nurses in primary care. Cochrane Database Syst Rev 2005 (2):001271

40. Laurant MG, Hermens RP, Braspenning JC, et al. An overview of patients' preference for, and satisfaction with, care provided by general practitioners and nurse practitioners. J Clin Nurs 2008;17:2690-8.

41. Martin-Misener R, Downe-Wamboldt B, Cain E, et al. Cost effectiveness and outcomes of a nurse practitioner-paramedicfamily physician model of care: the Long and Brier Islands study. Prim Health Care Res Dev 2009;10:14.

42. Richardson G, Maynard A, Cullum N, et al. Skill mix changes: substitution or service development? Health Policy 1998;45:119-32.

43. Thille P, Rowan MS. The role of nurse practitioners in the delivery of primary health care: a literature review. Health Canada, 2008. Contract No.: Report.

44. Adamek ME, Kaplan MS. Caring for depressed and suicidal older patients: a survey of physicians and nurse practitioners. Int $J$ Psychiatry Med 2000;30:111-25.

45. Carnwell R, Daly WM. Advanced nursing practitioners in primary care settings: an exploration of the developing roles. J Clin Nurs 2003;12:630-42.

46. OIIQ. Le réhaussement de la formation de la relève infirmière: un levier de transformation du système de santé. Un analyse coûts/ bénéfices. Montréal: Ordre des infirmières et infirmiers du Québec, 2013

47. Josette R. Les infirmières et infirmiers canadiens à la rescousse des soins de santé primaires. Santé Conjuguée. 2013;64:32-3.

48. Direction de santé publique, Institut National de Santé Publique du Québec, Fondation canadienne de la recherche sur les services de santé. Regarder en arrière pour mieux avancer: synthèse de l'évaluation de la réforme des soins de première ligne dans les provinces canadiennes. Montréal: Gouvernement du Québec, 2012.

49. AllC. Initiative Canadienne sur les Infirmières et Infirmiers Praticiens: Volet de la pratique Recherche documentaire Facteurs favorables et défavorables à la pratique. Ottawa: Association des infirmieres et infirmiers du Canada, 2005.

50. Cummings G, McLennan M. Advanced practice nursing: leadership to effect policy change. J Nurs Adm 2005;35:61-6.

51. DiCenso A, Bryant-Lukosius D. Infirmières cliniciennes spécialisées et infirmières praticiennes au Canada: Synthèse d'aide à la décision. Ottawa: Canadian Health Services Research Foundation Office of Nursing Policy, Health Canada, 2010.

52. Higuchi KA, Hagen B, Brown S, et al. A new role for advanced practice nurses in Canada: bridging the gap in health services for rural older adults. J Gerontol Nurs 2006;32:49-55.

53. Thrasher C, Purc-Stephenson RJ. Integrating nurse practitioners into Canadian emergency departments: a qualitative study of barriers and recommendations. CJEM 2007;9:275-81.

54. D'Amour D, Dubois C-A, Déry J, et al. Measuring actual scope of nursing practice: a new tool for nurse leaders. J Nurs Adm 2012;42:248-55.

55. Shortell SM, Schmittdiel J, Wang MC, et al. An empirical assessment of high-performing medical groups: results from a national study. Med Care Res Rev 2005;62:407-34.

56. Donabedian A. The quality of care. How can it be assessed? JAMA 1988;260:1743-8

57. Wilson K, Rosenberg MW. Accessibility and the Canadian health care system: squaring perceptions and realities. Health Policy 2004;67:137-48.
58. Beaulieu M-D, Haggerty JL, Beaulieu C, et al. Interpersonal communication from the patient perspective: comparison of primary healthcare evaluation instruments. Healthc Policy 2011;7:108-23.

59. Haggerty JL, Burge F, Beaulieu M-D, et al. Validation of instruments to evaluate primary healthcare from the patient perspective: overview of the method. Healthc Policy 2011;7:31-46.

60. Haggerty JL, Burge F, Lévesque J-F, et al. Operational definitions of attributes of primary health care: consensus among Canadian experts. Ann Fam Med 2007;5:336-44.

61. Pineault R, Lévesque J-F, Roberge $\mathrm{D}$, et al. Les modèles d'organisation des services de première ligne et l'expérience de soins dela population. Longueuil: Centre de recherche de l'Hôpital Charles LeMoyne, 2008.

62. Pineault R. L'accessibilité et la continuité des services de santé: une étude sur la première ligne au Québec: rapport de recherche soumis aux Instituts de recherche en santé du Canada (IRSC) et à la Fondation canadienne pour la recherche sur les services de santé (FCRSS). Centre de recherche de l'Hôpital Charles Lemoyne, 2008.

63. Waddington C, Egge D. Integrated health services-What and why? Technical brief no.1, 2008. Geneva: World Health Organisation, 2008.

64. Brousselle A, Lachaine J, Contandriopoulos A-P. L'évaluation économique. In: Brousselle $A$, Champagne $F$, Contandriopoulos A-P, Hartz Z, eds. Concepts et méthodes d'évaluation des interventions. Montreal: PUM, 2009:199-235.

65. Beaulieu M-D, Denis J-L, D'Amour D, et al. L'implantation des Groupes de médecine de famille: le défi de la réorganisation de la pratique et de la collaboration interprofessionnelle-Étude de cas dans cinq GMF de la première vague au Québec. Montréal: Chaire Docteur Sadok Besrour en médecine familiale-Recherche financée par la Fondation canadienne de la recherche sur les services de santé, le Fonds de la recherche en santé du Québec et la Direction de l'évaluation du ministère de la Santé et des Services sociaux., 2006.

66. Breton M, Lévesque J-F, Pineault R, et al. Integrating public health into local healthcare governance in Quebec: challenges in combining population and organizational perspectives. Healthc Policy 2009;4:e159-78.

67. Degani N. Impact of advanced (Open) access scheduling on patients with chronic diseases: an evidence-based analysis. Ont Health Technol Assess Ser 2013;13:1-48.

68. Rose KD, Ross JS, Horwitz LI. Advanced access scheduling outcomes: a systematic review. Arch Intern Med 2011;171:1150-9.

69. Murray M, Berwick DM. Advanced access. JAMA 2003;289:1035-40.

70. Murray M, Bodenheimer T, Rittenhouse $\mathrm{D}$, et al. Improving timely access to primary care. JAMA 2003;289:1042-6.

71. Enquête citoyenne. Résultats de l'enquête citoyenne portant sur les services de santé offerts aux citoyens de Natashquan et de Baie-Johan-Beetz. Le comité MICA de Baie-Johan-Beetz, Le conseil municipal de Baie-Johan-Beetz, Le comité de sauvegarde du poste infirmier de Natashquan et Le conseil municipale de Natashquan. 2011

72. Gauthier J, Haggerty J, Lamarche P, et al. Entre adaptabilité et fragilité: les conditions d'acces aux services de santé pour les communautés rurales et éloignées. Montréal: Institut national de santé publique du Québec, 2009. https://www.inspq.qc.ca/pdf/ publications/1014_ConditionsAccesServSanteCommunRurales.pdf

73. Groupe Recherche Focus. Sondage GRF pour le compte de Radio-Canada Côte-Nord. Les perceptions des Nord-côtiers en regard de certaines dimensions de leurs services de santé. Radio-Canada Côte-Nord. http://ici.radio-canada.ca/regions/greg/ fichiers/cnsondage1_8.pdf2003

74. OIIQ. La reconnaissance de la pratique infirmière en région éloignée. Mémoire du Comité consultatif sur la reconnaissance de la spécificité de la pratique infirmière en région éloignée. Montréal: Ordre des Infirmières et Infirmiers du Québec, 2004.

75. Rousseau N, Daigle J. Infirmières de colonie. Soins et médicalisation dans les régions du Québec, 1932-1972. Québec: Presse de l'Université Laval, 2013.

76. Fournier L, Lessard L, Aubé $\mathrm{D}$, et al. Modèles d'organisation des services de première ligne en santé mentale pour les personnes consultant dans les régions du Nunavik et des Terres-Cries-dela-Baie-James. Rapport final aux Instituts de recherche en santé du Canada, 2012.

77. Lessard L. La collaboration interdisciplinaire dans les régions isolées du Québec: Le cas des Terres-Cries-de-la-Baie-James. Mémoire de maîtrise: Université Laval, Québec, 2005. 
78. Minore B, Boone M, Katt M, et al. Facilitating the continuity of care for first nation clients within a regional context. Ottawa: FCRSS, 2001.

79. PRA Inc. Research \& Consulting. Evaluation of the Subdury District Nurse Practitioner Clinics. Final report prepared for the Ministry of Health and Long-Term Care. Evaluation report 2009 1rst October 2009.

80. Ministry of Health and Long-Term Care of Ontario. Nurse Practitioner-Led Clinics. 2012. http://www.health.gov.on.ca/en/pro/ programs/np clinics/default.aspx?pro

81. Nurse Practitioners' Association of Ontario. Nurse Practitioner-Led Clinics (NPLC). 2011. http://npao.org/nurse-practitioners/clinics/

82. Wedel R, Kalischuk RG, Patterson E, et al. Turning vision into reality: successful integration of primary health care in Taber, Canada. Healthc Policy 2007;3:80-95.

83. Chapple A, Rogers A, Macdonald W, et al. Patients' perceptions of changing professional boundaries and the future of nurse-led services. Prim Health Care Res Dev 2000;1:51-9.

84. Chapman JL, Zechel A, Carter YH, et al. Systematic review of recent innovations in service provision to improve access to primary care. Br J Gen Pract 2004;54:374-81.

85. Wong S, Farrally V. The utilization of nurse practitioners and physician assistants: a research synthesis prepared for the Michael Smith Foundation for health research. Vancouver: Michael Smith Foundation, 2013.

86. Horrocks S, Anderson E, Salisbury C. Systematic review of whether nurse practitioners working in primary care can provide equivalent care to doctors. BMJ 2002;324:819-23.

87. Courtenay M, Carey N. A review of the impact and effectiveness of nurse-led care in dermatology. J Clin Nurs 2007;16:122-8.

88. Büla CJ, Berod AC, Stuck AE, et al. Effectiveness of preventive in-home geriatric assessment in well functioning, community-dwelling older people: secondary analysis of a randomized trial. J Am Geriatr Soc 1999;47:389-95.

89. Leveille SG, Wagner EH, Davis C, et al. Preventing disability and managing chronic illness in frail older adults: a randomized trial of community-based partnership with primary care. J Am Geriatr Soc 1998;46:1191-8.

90. Carroll DL, Rankin SH, Cooper BA. The effects of a collaborative peer advisor/advanced practice nurse intervention: Cardiac rehabilitation participation and rehospitalization in older adults after a cardiac event. J Cardiovasc Nurs 2007;22:313-19.

91. Griffiths C, Foster G, Barnes N, et al. Specialist nurse intervention to reduce unscheduled asthma care in a deprived multiethnic area: the east London randomised controlled trial for high risk asthma (ELECTRA). BMJ 2004;328:144.

92. Sharples LD, Edmunds J, Bilton D, et al. A randomised controlled crossover trial of nurse practitioner versus doctor led outpatient care in a bronchiectasis clinic. Thorax 2002;57:661-6.

93. Krein SL, Klamerus ML, Vijan S, et al. Case management for patients with poorly controlled diabetes: a randomized trial. Am J Med 2004:116:732-9.

94. Scisney-Matlock M, Makos G, Saunders T, et al. Comparison of quality-of-hypertension-care indicators for groups treated by physician versus groups treated by physician-nurse team. J Am Acad Nurse Pract 2004;16:17-23.

95. Vadher BD, Patterson DL, Leaning M. Comparison of ora anticoagulant control by a nurse-practitioner using a compute decision-support system with that by clinicians. Clin Lab Haematol 1997;19:203-7.

96. Dellasega C, Zerbe TM. Caregivers of frail rural older adults. Effects of an advanced practice nursing intervention. J Gerontol Nurs 2002;28:40-9.

97. Naylor M, Kurtzman ET. The role of nurse practitioners in reinventing primary care. Health Aff 2010;29:893-9.

98. OCDE. Nurses in advanced roles: a description and evaluation of experiences in 12 developed countries. Paris, France: Organisation de Coopération et de Développement Economique, 2010. Retrieved July 10th 2010.

99. McDonald R, Campbell S, Lester $\mathrm{H}$. Practice nurses and the effects of the new general practitioner contract in the English National Health Service: the extension of a professional project? Soc Sci Med 2009;68:1206-12.

100. Shum C, Humphreys A, Wheeler D, et al. Nurse management of patients with minor illnesses in general practice: multicentre, randomised controlled trial. BMJ 2000;320:1038-43.

101. Fabrellas N, Vidal A, Amat G, et al. Nurse management of 'same day'consultation for patients with minor illnesses: results of an extended programme in primary care in Catalonia. $J$ Adv Nurs 2011;67:1811-16.
102. Iglesias B, Ramos F, Serrano B, et al. A randomized controlled trial of nurses vs. doctors in the resolution of acute disease of low complexity in primary care. J Adv Nurs 2013;69:2446-57.

103. Caldow J, Bond C, Ryan M, et al. Treatment of minor illness in primary care: a national survey of patient satisfaction, attitudes and preferences regarding a wider nursing role. Health Expect 2007; 10:30-45.

104. Rashid C. Benefits and limitations of nurses taking on aspects of the clinical role of doctors in primary care: integrative literature review. J Adv Nurs 2010;66:1658-70.

105. Redsell S, Stokes T, Jackson C, et al. Patients' accounts of the differences in nurses' and general practitioners' roles in primary care. J Adv Nurs 2007;57:172-80.

106. van Soeren M, Hurlock-Chorostecki C, Goodwin S, et al. The primary healthcare nurse practitioner in Ontario: a workforce study. Nurs Leadersh (Tor Ont) 2009;22:58-72.

107. MSSS. Les infirmières dans le groupes de médecine de famille. Québec: Ministère de la Santé et des Services Sociaux du Québec: Direction générale des affaires médicales et universitaires Équipe de projet des groupes de médecine de famille, 2002

108. MSSS. Evaluation de l'implantation et des effets des premiers groupes de médecine de famille au Québec. Québec: Ministère de la Santé et des Services sociaux Equipe d'évaluation des GMF Direction de l'évaluation, 2008.

109. Contandriopoulos D, D'Amour D, Dubois CA, et al. Infirmières praticiennes spécialisées de première ligne. 2013. http://ipspl.info/ index.html

110. Chaire Docteur Sadok Besrour en médecine familiale. L'équipe de première ligne: Une vision nouvelle, des nouvelles façons de faire. Montréeal, QC2002. http://www.fcass-cfhi.ca/Migrated/PDF/

ResearchReports/CommissionedResearch/record f.pdf

111. D'Amour D, Goulet L, Labadie JF, et al. A model and typology of collaboration between professionals in healthcare organizations. BMC Health Serv Res 2008;8:188.

112. Barrett J, Curran V, Glynn L, et al. CHSRF synthesis: interprofessional collaboration and quality primary healthcare. Ottawa, ON: Canadian Health Services Research Foundation 2007. Contract No.: Report

113. Jones L, Way D. Practice component: literature review report Delivering primary health care to Canadians: nurse practitioners and physicians in collaboration. Ottawa, ON: Canadian Nurses Association \& Canadian Nurse Practitioner Initiative, 2004 Retrieved March 2nd, 2009.

114. Murray L, Reidy M, Carnavale FA. Stakeholders'conceptualization of the nurse practitioner role in the pediatric emergency department. Can J Nurs Leadersh 2010;22:88-100.

115. van Soeren MH, Micevski V. Success indicators and barriers to acute nurse practitioner role implementation in four Ontario hospitals. AACN Clin Issues 2001;12:424-37.

116. OIIQ. Mémoire: Les infirmières praticiennes spécialisées: un rôle à propulser, une intégration à accélérer-Bilan et perspectives de pérennité. Montréal: Ordre des infirmières et infirmiers du Québec, 2009

117. Hamel M, Pineault R, Levesque J-F, et al. Résumé : L'organisation des services de santé en première ligne-Portrait des services médicaux de première ligne à Montréal et en Montérégie. Longueuil: Centre de recherche de l'Hôpital Charles LeMoyne, 2008

118. CIHI. National Physician Database, 2011-2012-data release. Ottawa: Canadian Institute for Health Information, 2013.

119. Haggerty JL. Measurement of primary healthcare attributes from the patient perspective. Healthc Policy 2011;7:13-20.

120. Wong FKY, Chung LCY. Establishing a definition for a nurse-led clinic: structure, process, and outcome. J Adv Nurs 2006;53:358-69.

121. Richardson A, Cunliffe L. New horizons: the motives, diversity and future of 'nurse led' care. J Nurs Manag 2003;11:80-4

122. Hansen-Turton T, Miller M. Nurses and nurse-managed health centers fill healthcare gaps. Pa Nurse 2006;61:18.

123. DiCenso A, Bourgeault I, Abelson J, et al. Utilization of nurse practitioners to increase patient access to primary healthcare in Canada-thinking outside the box. Can J Nurs Leadersh 2010;23:239-59.

124. Patton MQ. Developmental evaluation: applying complexity concepts to enhance innovation and use. New-York: The Guilford Press, 2011.

125. Patton MQ. Developmental evaluation (slides). Ottawa: Présentation à la conférence conjointe de la Société Canadienne d'Évaluation et de la American Evaluation Association, 2009.

126. Patton MQ. Developmental evaluation. Eval Pract 1994;15:311-19. 
127. Champagne F, Brousselle A, Contandriopoulos A-P, L'analyse des effets. In: Brousselle A, Champagne F, Contandriopoulos A-P, et al. eds. Concepts et méthodes d'évaluation des interventions. Montreal: PUM, 2009:173-98.

128. Champagne F, Brousselle A, Contandriopoulos A-P, L'analyse logique. In: Brousselle A, Champagne F, Contandriopoulos A-P, Hartz Z, eds. Concepts et méthodes d'évaluation des interventions. Montreal: PUM, 2009:103-12.

129. Brousselle A, Champagne F. Program theory evaluation: logic analysis. Eval Program Plann 2011;34:69-78.

130. Contandriopoulos D, D'Amour D, Brousselle A, et al. Soutenir le déploiement des infirmières praticiennes (IPS) de première ligne au Québec. IRSC-PASS, 2011.

131. Pawson R. Evidence-based policy: the promise of 'realist synthesis'. Eval Program Plann 2002;8:340-58.

132. Pawson R, Greenhalgh T, Harvey G, et al. Realist review-a new method of systematic review designed for complex policy interventions. J Health Serv Res Policy 2005;10(Suppl 1):21-34.

133. Brousselle A, Contandriopoulos D, Lemire M. How logic analysis can be used to evaluate knowledge transfer initiatives: the case of the Research Collective on the Organization of Primary Care Services. Evaluation (Lond) 2008;15:165-83.

134. Contandriopoulos D, Brousselle A. Fostering evaluation use: lessons from a large systematic review on knowledge transfer. Actes du congrès bisannuel de l'European Evaluation Society. 2010. Proceedings from the 9th European Evaluation Society. 2010. Prague 6-8 Octobre (S3-07 p.33). http://www. europeanevaluation.org/sites/default/files/events/ees-abstract book_2010-web.pdf

135. Contandriopoulos D, Lemire M, Denis J-L, et al. Knowledge exchange processes in organizations and policy arenas: a narrative systematic review of the literature. Milbank Q 2010;88:444-83.

136. Scriven M. Types of evaluation and types of evaluator. Am J Eval 1996;17:151-61.

137. Scriven M. Evaluation thesaurus. Newbury Park: SAGE, 1994.

138. Barrett S, Hill M. Policy, bargaining and structure in implementation theory: towards an integrated perspective. Policy Polit 1984;12:219-40.

139. Hjern B, Porter DO. Implementation structures: a new unit of administrative analysis. Organ Stud 1981;2:211-27.

140. Hjern B. Review: implementation research: the link gone missing $J$ Public Policy 1982;2:301-8.

141. Maynard-Moody S, Musheno M, Palumbo D. Street-wise social policy: resolving the dilemma of street-level influence and successful implementation. West Polit Q 1990;43:833-48.

142. Kickert WJM, Klijn E-H, Koppenjan JFM. Managing implementation processes in networks. In: Kickert WJM, Klijn E-H, Koppenjan J, FM, eds. Managing complex networks. London: SAGE Publications, 1999:137-51.

143. O'Toole LJ Jr. Multiplicity in the implementation setting: subtle impacts and the case of wastewater treatment privatization. Policy Stud J 1989;18:1-20.

144. O'Toole LJ Jr. Policy recommendations for multi-actor implementation: an assessment of the field. J Public Policy 1986;6:181-210.

145. Matland RE. Synthesizing the implementation literature: the ambiguity-conflict model of policy implementation. J Public Adm Res Theory 1995;5:145-74

146. Sabatier PA. Top-down and bottom-up approaches to implementation research: a critical analysis and suggested synthesis. J Public Policy 1986;6:21-48.

147. Patton MQ. Qualitative research \& evaluation methods. 3rd edn. Thousand Oaks: Sage Publications, 2002.

148. Denzin NK. The research act: $A$ theoretical introduction to sociological methods. New York: McGraw-Hill, 1978.

149. Hardy C, Palmer I, Philips N. Discourse as a strategic resource. Hum Relations 2000;53:1227-48.

150. Chouliaraki L, Fairclough N. Discourse in late modernity: rethinking critical discourse analysis. Edinburgh: Edinburgh University Press, 1999.

151. Moch MK, Fields WC. Developing a content analysis for interpreting language use in organizations. Res Sociol Organ 1985;4:81-126.

152. Kirsch C, Bernier B. Le sens du discours écrit: propos méthodologiques à partir de deux recherches. Culture 1988;VIII (1):35-47.

153. Bourdieu P. Ce que parler veut dire: l'économie des échanges linguistiques. Paris: Fayard, 1982.

154. Ranmuthugala G, Plumb JJ, Cunningham FC, et al. How and why communities of practice established in the healthcare sector? A systematic review of the literature. BMC Health Serv Res 2011:11:273.

155. Andrew N, Tolson D, Ferguson D. Building on Wenger: communities of practice in nursing. Nurse Educ Today 2008;28:246-52.

156. Diem E, Moyer A, MacDonald M. Model of communities of practice for advancing practice in community health nursing. Final Report and Resource Package submitted to Community Health Nurses of Canada. 2009.

157. Wenger E. Communities of practice: learning, meaning, and identity. Cambridge: Cambridge University Press, 1998.

158. Wenger E, McDermott R, Snyder W. Cultivating communities of practice. Boston: Harvard Business Review Press, 2002.

159. Mohr LB. Explaining organisational behavior. San Francisco: Jossey-Bass, 1982.

160. Langley A. Stratégies de l'analyse de données processuelles. Montréal: Centre de recherche en gestion de l'Université du Québec à Montréal, 1996.

161. Pettigrew AM. Longitudinal field research on change: theory and practice. Organ Sci 1990;1:267-92.

162. Pettigrew AM. The character and significance of strategy process research. Strateg Manag J 1992;13:5-16.

163. Nagel P. Policy games and venue-shopping: working the stakeholder interface to broker policy change in rehabilitation services. Aust J Public Adm 2006;65:3-16.

164. Yin RK. Case study research: design and methods. Revised ed. Applied Social Research Methods Series. Newbury Park: Sage, 1989.

165. Lix L, Yogendran M, Mann J. Defining and validating chronic diseases: an administrative data approach. An update with ICD-10-CA. Winnipeg: Manitoba Centre for Health Policy, University of Manitoba, 2008.

166. ASSS Montréal. L'utilisation des services de santé par les Montréalais atteints d'une maladie chronique et pour l'ensemble des utilisateurs-Années 2001-2002 à 2009-2010. Agence de la Santé et des Services Sociaux de Montréal, 2013. http://emis. santemontreal.qc.ca/fileadmin/emis/Sant\%C3\%A9_des_Montr\% C3\%A9alais/\%C3\%89tat_de_sant\%C3\%A9/sant\%C3\%A9_ physique/Utilisation_des_services_de_sante/Description_des_ indicateurs_et_variables.pdf

167. Gardarsdottir $\bar{H}$, Egberts AC, van Dijk L, et al. An algorithm to identify antidepressant users with a diagnosis of depression from prescription data. Pharmacoepidemiol Drug Saf 2009;18:7-15.

168. Santor DA, Haggerty JL, Lévesque J-F, et al. An overview of confirmatory factor analysis and item response analysis applied to instruments to evaluate primary healthcare. Healthc Policy 2011;7:79-92.

169. Eco-Santé. Annexe 12: Les NIRRU. Détermination d'un indice de lourdeur associé aux patients hospitalisés dans un CHSGS et regroupés par APR-DRG. 2012. Ministère de la Santé et des Services Sociaux du Québec. 2012. http://www.ecosante.fr/ QUEBFRA/11200.html

170. McWilliams JM, Zaslavsky AM, Meara E, et al. Impact of Medicare coverage on basic clinical services for previously uninsured adults. JAMA 2003;290:757-64.

171. Rosenthal MB, Frank RG, Li Z, et al. Early experience with pay-for-performance: from concept to practice. JAMA 2005;294:1788-93.

172. Rubin DB. Estimating causal effects from large data sets using propensity scores. Ann Intern Med 1997;127:757-63.

173. Contandriopoulos D. Some thoughts on the field of KTE. Healthc Policy 2012;7:32-40.

174. Contandriopoulos D, Brousselle A. Evaluation models and evaluation use. Evaluation 2012;18:61-77.

175. Contandriopoulos D, Brousselle A, Kêdoté NM. Evaluating interventions aimed at promoting information utilization in organizations and systems. Healthc Policy 2008;4:89-107.

176. Feldman MS, March JG. Information in organizations as signal and symbol. Adm Sci Q 1981;26:171-86.

177. Knott $\mathrm{J}$, Wildavsky $\mathrm{A}$. If dissemination is the solution, what is the problem? Knowledge Creation Diffusion Utilization 1980;1:537-78.

178. Alvesson M, Spicer A. A stupidity-based theory of organizations. J Manag Stud 2013;49:1194-220.

179. Haggerty JL, Lévesque J-F, Santor DA, et al. Accessibility from the patient perspective: comparison of primary healthcare evaluation instruments. Healthc Policy 2011;7:94-107.

180. Shi L, Starfield B, Xu J. Validating the adult primary care assessment tool. J Fam Pract 2001;50:161-71.

181. Flocke $S$. Measuring attributes of primary care: development of a new instrument. J Fam Pract 1997;45:64-74. 
182. Katz A, Coster CD, Bogdanovic B, et al. Using administrative data to develop indicators of quality in family practice. Manitoba Centre for Health Policy, Department of Community Health Sciences Faculty of Medicine, University of Manitoba, 2004. http:// mchp-appserv.cpe.umanitoba.ca/reference/quality_wo.pdf

183. Tousignant $P$, Beaulne $G$, Feldman $D$, et al. Plan de monitorage interprétatif de l'impact des transformations des services de santé de première ligne sur la population montréalaise. Agence de Développement de Réseaux Locaux de Services de Santé et de Services Sociaux de Montréal-Direction de Santé Publique Institut National de Santé Publique du Québec, 2005.

184. Borowsky SJ, Nelson DB, Fortney JC, et al. VA community-based outpatient clinics: performance measures based on patient perceptions of care. Med Care 2002;40:578-86.

185. Haggerty JL, Burge F, Pineault R, et al. Management continuity from the patient perspective: comparison of primary healthcare evaluation instruments. Healthc Policy 2011;7:139-53.

186. Burge F, Haggerty JL, Pineault R, et al. Relational continuity from the patient perspective: comparison of primary healthcare evaluation instruments. Healthc Policy 2011; 7:124-38.

187. Safran DG, Kosinski M, Tarlov AR, et al. The primary care assessment survey: tests of data quality and measurement performance. Med Care 1998;36:728-39.

188. Haggerty JL, Beaulieu M-D, Pineault R, et al. Comprehensiveness of care from the patient perspective: comparison of primary healthcare evaluation instruments. Healthc Policy 2011;7:154-66.

189. Ware JEJ, Kosinski M, Keller SD. A 12-item short-form health survey: construction of scales and preliminary tests of reliability and validity. Med Care 1996;34:220-33. 